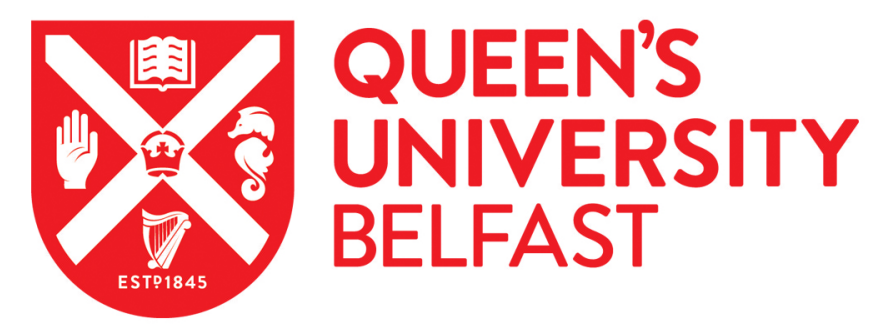

\title{
Irony as discipline: Self-help and gender in the knowledge economy
}

Kenny, K., \& Bell, E. (2014). Irony as discipline: Self-help and gender in the knowledge economy: Self-help and gender in the knowledge economy. Social Politics, 21(4), 562-584. https://doi.org/10.1093/sp/jxu012

\section{Published in:}

Social Politics

\section{Document Version:}

Early version, also known as pre-print

Queen's University Belfast - Research Portal:

Link to publication record in Queen's University Belfast Research Portal

Publisher rights

Copyright 2014 The author(s)

\section{General rights}

Copyright for the publications made accessible via the Queen's University Belfast Research Portal is retained by the author(s) and / or other copyright owners and it is a condition of accessing these publications that users recognise and abide by the legal requirements associated with these rights.

Take down policy

The Research Portal is Queen's institutional repository that provides access to Queen's research output. Every effort has been made to ensure that content in the Research Portal does not infringe any person's rights, or applicable UK laws. If you discover content in the Research Portal that you believe breaches copyright or violates any law, please contact openaccess@qub.ac.uk. 
Irony as discipline: Self-help and gender in the knowledge economy

Kate Kenny and Emma Bell

Please reference as:

Kenny, K. \& Bell, E. (2014). Irony as Discipline: Self-Help and Gender in the Knowledge Economy. Social Politics, 21 (4): 562-584.

The final, definitive version of this paper has been published in Social Politics by Oxford Journals. All rights reserved. (C) This is the pre-print version, posted by the first author on the Queen's University Belfast website under the terms of the contributor agreement.

Accepted version, final publication:

http://sp.oxfordjournals.org/content/early/2014/06/24/sp.jxu012.abstract 


\begin{abstract}
In this paper we explore the role of self-help literature within the knowledge economy. We point to the recent growth of ironic humour within such texts, and examine how this operates to construct gendered and embodied subjectivities that position women according to a masculine gaze. Drawing on empirical data from self-help books for career women published between 1997 and 2007, we analyze the styles of embodiment that these texts promote. We find that career women are encouraged to maintain a stance of constant attention to themselves and their bodily presentations, a position that is in line with wider cultural features of contemporary knowledge economy working. We note that ironic humour is deployed in ways that subtly reinforce existing gender relations within contemporary organizations. Our paper contributes to debates on subjectivity within the knowledge economy; while scholars have pointed to an increasing normative emphasis on embodied performances, we provide insights into the mechanisms by which this occurs, with a specific focus upon the growing genre of self-help literature and its recent shift to ironic humour.

\section{Introduction}

In the early years of the knowledge economy, some scholars were enthusiastic about the potential for knowledge workers to overcome traditional gender inequalities by creating new opportunities and providing greater 'gender equity in personal and professional life' (Eaton, 1999: 175). Others were more circumspect, arguing that 
work in the knowledge economy is ambivalent in relation to gender positions (Truss et al., 2012; Wajcman, 2004). In this paper we explore the changing nature of gender relations in the knowledge economy, through focusing on self-help books aimed at career women whose publication is coterminous with the rise of the knowledge economy in the context of neoliberal discourses. Building on earlier studies of selfhelp literature for career women, we offer an analysis of the seven most popular guides published between 1997 and 2007. We show how this technology of the self (Rose, 1989) places normative pressure on career women to discipline themselves through the adoption of particular styles of workplace embodiment. By advising women to use their bodies in order to get ahead, these texts represent a means through which control over women's subjectivities is exerted. A crucial difference that distinguishes these texts from earlier ones is the ironic humour that characterises it, exemplified by titles such as How to Succeed in Business without a Penis and Nice Girls Don't Get the Corner Office.

We begin by reviewing the significance of self-help literature against the backdrop of increasingly influential neoliberal discourses in the knowledge economy, with a focus on issues relating to gender and embodiment and the role of the male gaze in constructing the aesthetic self. Next we introduce the concept of humour as a disciplinary mechanism in contemporary organizations. This helps to illuminate the shift in tone that has occurred in self-help texts in order to take account of changes in the gendered cultures of work in the context of the knowledge economy and neoliberalism. We then present our analysis of advice relating to the gendered body that contemporary self-help books offer to career women. We show how this relies 
on the stylistic use of ironic humour to ideationally distance the reader from these bodily norms whilst simultaneously entreating her to conform to them.

\section{Constructing normative subjectivities through the cultural circuit of the}

\section{knowledge economy}

Self-help books propose to help women to find out about ourselves, to teach us effective ways of being. (Simonds, 1992: 223).

Historically speaking, self-help books have constituted an important aspect of popular culture, consumed by mass audiences for more than a century (Biggart, 1983). This reflects the culture of individualism that characterises liberal market economies, particularly American society, through promoting core values of achievement, selfreliance, hard work and conformity (Schneider and Dornbusch, 1958). In the last three decades the popularity of these texts has increased significantly; between 1972 and 2000 the number of self-help books in print has more than doubled, and between 1991 and 1996 sales increased by 96\% (McGee, 2005). This growth needs to be understood, in the context of the dominance of neoliberal discourses, as a reflection of the expectation upon individuals to be self-reliant, entrepreneurial, rational and calculating. These popular texts thereby form part of a cultural project of subjectification through which personal responsibility, based on independent selfsufficiency and future oriented self-discipline, combined with entrepreneurialism as the articulation of agency, activeness and personal initiative, form the basis for the construction of a normative pedagogy of selfhood (Joseph, 2013). 
The growth in popularity of self-help literature has also taken place in the context of the rise of the knowledge economy, characterised by the shift from producing tangible products, towards making, distributing and using intangible forms of information. Knowledge-intensive firms create value through the application of different types of knowledge to meet client demands (Truss et al., 2012). These organisations rely on highly-skilled and well-educated knowledge workers, who must be flexible, creative and innovative (Nonaka and Takeuchi, 1995), and active in maintaining social networks and informal connections with others. Alongside this however, there has been a rise in part-time and temporary working arrangements. This results from the need to distinguish between 'core' and 'periphery' (i.e. dispensable) workers in the name of organizational flexibility, resulting in increased precariousness of working life for many (Thurow, 2000). Here we define the knowledge economy holistically considering its impact on all forms of employment, not just jobs in high-technology and knowledge-intensive sectors, through changes in the 'spatiality, temporality and contractuality of work' (Walby, 2007: 8) arising as a result of increased global competitive pressures (see also Sennett, 1998).

For Thrift (2005), a key aspect of knowledge economy capitalism is the cultural circuit, a self-reinforcing system of knowledge production in which problems are identified that can only be solved by applying prescriptive knowledge produced by the system itself. An example relevant to this paper relates to management gurus who have become key figures in the contemporary cultural circuit of capital (Crainer, 1996, Clark and Salaman, 1998; Huczynski, 1993; Jackson, 2001). These individuals advise workers in the knowledge economy on how they might survive in this precarious 
working environment, and as critics note, this advice ultimately reinforces the validity of new, insecure conditions of employment. A new kind of self-disciplining subject emerges, who continuously monitors herself in order to ensure that she is presenting an image suitable for this new world of work (Rose, 1989). Self-help literature for women plays an important role within the cultural circuit of the knowledge economy, by claiming to help readers adjust to neoliberal capitalism. These texts urge individuals to embody hyper-individualism by making 'themselves into objects of analysis and improvement' (Simonds, 1992: 223), thereby commodifying their labour in accordance with a neoliberalist ethos.

However, the effects of discourses of neoliberalism and globalisation in the context of the knowledge economy are not gender neutral (Acker, 2004). Women remain underrepresented in knowledge-intensive industries such as ICT and may be less able to translate educational qualifications into employment assets (Walby, 2007). We must therefore avoid privileging neoliberalism as a master category (Larner et al., 2013) and instead seek to explore how the values and embodied expressions of neoliberal ideology differentially affect women through the increased value that this regime places on culturally encoded performances of femininity (Larner et al., 2013), combined with the association of success in work hierarchies with a hegemonic hyper-masculinity that is 'aggressive, ruthless, competitive and adversarial (Acker, 2004: 29). A key question then is whether these changes have led to a de-gendering or a re-gendering of employment practices. One way of exploring how neoliberalism has affected the position of women in traditional work hierarchies is through analysis of self-help books written for and by career women, since such texts enable 
understanding of how the 'performativity of gender and gender relations both reflects and constitutes changing material and social conditions' (Larner, et al, 2013). As others have noted (Koester, 1982; Bate and Self, 1983; McGee, 2005), these texts contribute to increasing pressures upon working women to discipline and control their bodies through the intersection of discourses of enterprise and therapy (Nadesan and Tretheway, 2000). Such discourses encourage career women to discipline their minds and bodies in order to present a more entrepreneurial self through the display of characteristics that are traditionally seen as masculine. These texts are based on the premise that women's bodies are inherently other in the contemporary workplace, offering advice to women readers on how to minimize the effects of this (Authors, 2011). The findings are supported by studies of gender and organization that suggest there is no neutral bodily norm within organizations, the normal body being defined implicitly as masculine. In this context, the female body is inherently sexual, dangerous, suspicious, volatile and disruptive (Acker, 1990; Cockburn, 1991; Burrell, 1992; Sinclair, 2011). Self-help books offer advice on how to discipline the female body to ensure that these features do not damage one's career progress.

A key aspect of this control involves continuous self-monitoring. An example of this can be found in Ehrenreich's autobiographical study of contemporary white-collar work in the U.S. where she is advised to attend a colour analysis session: 'I am suddenly gripped by queasiness', she notes. 'I understand that to make myself into a "product" that I can market, I must first become a commodity... What I had not understood is that to become an object, a thing, you must first go through a kind of death' (Ehrenreich, 2006: 111). Ehrenreich describes the pressure to see herself as a 
'thing': to be monitored and controlled. In addition, this excerpt illustrates the commoditization of the female body, as women workers are increasingly under pressure to view their bodies as aesthetic commodities with a marketable value that can be bought and sold (Ehrenreich, 2006; Hancock and Tyler, 2000; Hochschild, 1983; Witz et al., 2003).

What role has feminism played in the emergence of self-help for women? Hochschild (1994) suggests that while the principle of equality has been taken from feminism and used to make way for women in public life, this shift relies on greater emotional detachment and more instrumentalized relationships. Rather than promoting feminism, she argues that self-help literature abducts and commercializes it. One must discipline oneself in order to maintain the 'product', the body, in a saleable condition, even where this engenders feelings of alienation and discomfort (Dean, 2005), as described above by Ehrenreich. The intensification of this 'feedback loop', of continuous monitoring of one's aesthetic image, is enhanced by the self-help industry. Such arguments illustrate the uneasy relationship between neoliberal discourses and feminism, through the emergence of a more individualized style of feminism that espouses feminism's basic principles, whilst remaining compatible with the central tenets of neoliberalism.

A number of scholars have argued that a fundamental paradox operates within these texts. The self-help literature suggests that being a career woman entails conformity to a permitted range of 'looks, behaviours and feelings to ensure that career women are not seen as "too" feminine or "not feminine enough" (Hochschild, 1994: 279). For example, women are encouraged to use their sexuality to their advantage by 
strategically flirting, while at the same time they are advised that their sexuality is dangerous and must be repressed (Authors, 2011). Ehrenreich captures this ambiguity well through her account of an image management consultation. She is told by the image consultant that her appearance is 'too authoritative', a judgement that Ehrenreich interprets as 'not looking feminine enough'. She goes on, 'the dress-forsuccess books all urge what I take to be a somewhat mannish appearance, achieved through pragmatic hairstyles and curve-concealing suits. But if you go too far in the masculine direction... you somehow err again' (Ehrenreich, 2006: 108). The guidelines presented on how to negotiate this oscillation between 'masculine' positions of power and apparently intractable female bodily obstacles, are ultimately contradictory. These confusing recommendations are impossible to follow since there is no coherent ideal woman's body to emulate. An achievable feminine embodied position therefore does not exist and is impossible to attain.

Feminist writers have also addressed ideas of paradox and of monitoring in relation to gendered self presentation. Dean (2005) draws on Mulvey's concept of the gaze to suggest that the continual monitoring of one's aesthetic self is particularly complex and problematic for women. Mulvey's (1975) observations suggest that women are often placed, and place themselves, in the imagined gaze of the male onlooker. This creates a paradox in which the female viewer is always divided between identifying with the passive female object and the active male position of viewer. Hence the career woman's own gaze can never be 'fully female', but is always mediated by anticipation of the male viewer (Harding, 2013). 
Such arguments echo Irigaray's (1990) view of sexual difference as a normative category constructed by patriarchal societies that valorize the male subject as universal and more valuable. For Irigaray, discourses of equality are counterproductive for women because "“equal" tends to mean "equal to men" and therefore equivalent to the imposition of a male norm' (Whitford, 1991: 23). Western cultures, she argues, have treated women as different from men without granting them any positive content, only strangeness and aberration. Consequently, female sexuality and female modes of embodied being are defined, according to masculine parameters, as an absence: not even afforded the negative category of subordinate subject. Rather than privileging the category of man over woman, Irigaray asserts that these cultures subsume woman as a category that can only be understood relative to man, as his reflection, the 'other of the same'. For her, equality comes at a cost as women are required to pay a physical and psychological price for their participation in the 'between-men' economy and culture.

The current social order, and that includes the order defining occupations, is not neutral when viewed in terms of the differences of the sexes... in order to achieve a minimum of freedom, women have to subject themselves to the imperatives of a culture that is not their own... they do enter the workplace, but in so doing they alienate their female identity... there is still hardly any sort of work that enables a woman to earn her living as a male citizen does without alienating her identity in working conditions and contexts developed to suit men alone (Irigaray, 1990: 78-9)

For this reason it is crucial, she suggests, for women to do more than simply try to become more like men because this involves accepting a masculine discourse that 10 
inevitably rejects them. Through critiquing the homogenizing tendencies of Western culture, Irigaray argues for the construction of an alternative to male consciousness in the form of a female subjectivity that is not defined according to masculine parameters as a negative or lack.

We therefore see the construction of gender identity as a relational social process in the knowledge economy, which is shaped by discourses of neoliberalism in a way that simultaneously enables and constrains women's possibilities in the workplace. Selfhelp texts construct gender as a fundamentally embodied category that affects how women see and experience themselves in organizations; women position themselves within and in comparison to the discourses contained within these texts. Through prescribing how gender ought to be performed in such contexts, they contribute towards the continual reiteration and reconfirmation of gender difference in the workplace as a powerful norm or script (Joseph, 2013). In the remainder of this paper we examine recent changes in the way self-help texts for women are presented. First however we outline a further aspect of gender and subjective discipline that is central to our analysis of self-help in the knowledge economy - the role of humour.

\section{Humour, irony and self-discipline}

Within contemporary organizations, humour can be deployed in subtle and indirect ways in order to promote particular forms of self-discipline among employees, and maintain the status quo in relation to existing hierarchies of power. Companies sometimes use what Bolton and Houlihan refer to as 'packaged fun' as a means to appease employees and generate a sense of inclusiveness (2009: 557, see also Fleming, 2007), while Greatbatch and Clark (2003) show how humour can be used 11 
strategically by managers to influence their employees (see also Kahn, 1989). Cooper (2005) argues that convincing people to go along with new initiatives can be greatly helped when change managers use humour. The idea here is that humour can be deployed in ways that generate 'positive affect' in order to influence 'the target', that is the employee (Cooper, 2005, p. 773). For Andriopoulos and Gotsi (2001) and Montuori (2003), the deployment of humour plays a key role for managers in their strategic engendering of creativity within the creative industry firms they study.

In some cases, the role of humour in maintaining existing relations of power is yet more subtle. For example, Kenny and Euchler (2012) examine humorous emails that circulate in an advertising agency. They point out that although ostensibly 'fun' and neutral, such email jokes in many cases operate to maintain existing gendered structures by subtly reinforcing norms of masculinity. In Collinson's (1992) Managing the Shop Floor, he reports how in-jokes and humour support and reinforce the strong homosocial ties that characterized the team of shop-floor workers he studied. However, he notes it was this dynamic that contributed to the men being unable, or unwilling, to change and adapt to new structures and cultural practices within the organization, contributing to their eventual redundancy.

Within this use of humour as a means to maintain existing power relations, irony plays an important role. As Parker (2007) points out, irony can be deployed in ways that while ostensibly subversive, may merely act to reinforce the status quo. He references the sale of office paraphernalia including mugs and t-shirts that feature ironic slogans, such as 'you don't have to be mad to work here, but it helps' (2007: 77). Humour can give the impression that a negation of power is occurring, while in 12 
many cases it acts to provide a 'safety valve' for resistant impulses, ultimately acting to reinforce the status quo (Foucault, 1990; Gherardi, 1995; Butler, 1993), an idea to which we later return.

Before proceeding, it is important to explain what we mean by ironic humour. An ironic statement is one that implicitly asks the reader to interpret what is being said in opposition to its literal meaning (Trethewey, 1999b); for example one might say 'good job!' when in fact a mistake has been made. Communication scholars have pointed to the uses and effects of irony in rhetorical situations, noting that its stylistic impact is to suggest that the author is complicit with social conventions to a certain extent, while at the same time wishing to appear detached from them. This can be achieved through ironic statements that imply 'simultaneous seriousness and play' (Trethewey, 1999b: 143). As we will show, this concept is helpful in understanding the messages put forward by the self-help texts that form the focus of this paper.

\section{Studying self-help}

This paper draws on material collected during a broader study of self-help books aimed at career women, published between 1970 and 2007 (Authors, 2011). In this analysis we focus on those published since 1997 as reflective of a change in tone that indicates a shift in the gendered discourses of neoliberalism in the knowledge economy. Three criteria drove our selection of texts: first, we chose books aimed at a general, popular audience as indicated by the title and cover images, book sales figures and library holdings, along with popularity on Amazon. A second criteria was to select books that claimed to help women to improve their career prospects by offering practical advice and suggestions. Thirdly, we focused on books aimed at 13 
professional career women working as managers and professionals in the knowledge economy; these texts generally assume that women work in large-scale bureaucratic organizations, but a few are oriented towards female entrepreneurs. Finally, we confined our sample to books published in English, written by authors based in North America, the UK and Australia, as liberal market economies where knowledgeintensive work is most prevalent.

A consistent feature of the texts relates to authorial voice and style. Nearly all the books are written by women, many of whom have built successful careers in business. The authors adopt an informal, conversational tone towards the reader, acting as a friend rather than a professional expert and conveying inspirational ideas and images through telling parable-like stories about other women who have been successful. Advisors assert that the issues women confront in building a successful managerial career are different or exceptional and require separate consideration. Advice is typically geared towards helping the career woman to survive in a hostile environment and get to the top of the organizational hierarchy through her own individual efforts. As Koester (1982) notes, these books constitute gender as the primary variable in determining the success of the career woman, rather than skill, competence, education or individual characteristics.

While it is not possible to accurately assess the extent to which women who read these self-help books either accept the social reality they portray, or implement the advice they offer, the ongoing popularity of these books provides indirect evidence to suggest that they constitute an important means of expressing a dominant vision of organizational life to which large numbers of women relate (Koester, 1982; Authors, 14 
2011). Data analysis followed an abductive strategy, based on continual weaving between data and theoretical ideas in order to identify and develop emergent themes (Wodak, 2004). Drawing on previous studies of self-help and career women, we remained sensitive to advice that professional advisors give to readers on how to present and position their bodies. Having isolated emergent themes, further iteration between data and theory took place.

Ironic humour was identified as a central resource used to co-opt the reader into appropriate conceptions of gendered embodiment. In the following section, we trace representations of the female body within contemporary self-help literature aimed at career women. We illustrate the varying ways in which gender is organized and regulated, and highlight the role of humour in communicating a range of femininities that are permitted, as well communicating as those that are forbidden.

\section{Playing the game}

A distinct feature of self-help books published after 1997 is a shift to a less serious, light-hearted tone. This is reflected in the almost ubiquitous use of the metaphor of the game; career women are told to think of their career progression in these terms. Playing the part of the manager is represented through the extensive use of sporting metaphors, such as Play Like a Man, Win like a Woman (2004), Hardball for Women: Winning at the Game of Business (2005) ${ }^{\mathrm{i}}$, and Opening up the Heavily Guarded Alpha Male Playbook (2007).

In relation to the content of these texts, while previous authors adopt a more serious, instructive style, recent books are more humorous: 
'It's hard enough to succeed in business with a penis these days, let alone without one.' How to Succeed in Business without a Penis: Secrets and Strategies for the Working Woman (1996).

Advice on dress, for example, is more fun than in previous years:

'Nothing zaps your confidence faster than being accused of being (or feeling) inappropriately dressed... Unless you've got the legs, save the mini-skirts for the weekend.' The Girl's Guide to Being a Boss: Valuable Lessons and Smart Suggestions for Making the Most of Managing (2004)

In general, the tone of recent texts is that of a jokey friend, who feels close enough to her reader to be in a position to point out her flaws:

'Think carefully about what signals the clothes you are wearing are sending out and how appropriate they are. Blinging accessories and fur ponchos might be appropriate for Victoria Beckham but, unless you are in the fashion industry, a footballer's wife or a pop star, you'll need to tone it down.' In Good Company: The Essential Business Start-Up Guide for Women (2006)

Previous studies of gender and embodiment have shown that women's bodies and embodied behaviours represent potentially disastrous obstacles to achieving success at work (Hochschild, 1994; Trethewey, 1999a; Authors, 2011). This perspective is reiterated in the books analyzed here, but the discourse is presented more casually. This is perhaps best encapsulated in Nice Girls Don't Get the Corner Office. The entire book is structured around the ' 101 unconscious mistakes women make that sabotage their careers' (cover slogan). One by one, each potential pitfall is detailed, 16 
followed by advice on how to overcome it. Mistakes include limp handshakes (mistake 28), the 'stereotypical female attribute' of 'feeding others' at work (mistake 27), and speaking at a higher than natural pitch (mistake 70). In Chapter 6, an exhaustive account of the failings of women in relation to 'how they sound' is provided. These include:

'Couching statements as questions, Using Preambles, Explaining, Asking Permission, Apologizing, Using Minimizing Words, Using Qualifiers, Not Answering the Question, Talking Too Fast, The Inability to speak the language of your business, Using Nonwords, Using Touchy-Feely language, The Sandwich, Speaking softly, Speaking at a higher than natural pitch, Trailing voicemails, Failing to Pause or Reflect before Responding.' Nice Girls Don't Get the Corner Office: 101 Unconscious Mistakes That Women Make (2004)

A similar tone is clear in Play like a man: Win Like a Woman: What Men Know about Success that Women Need to Learn (2000):

'They can cry. You can't...

They can have sex. You can't...

They can fidget. You can't...

They can yell. You can't...

They can be ugly. You can't...' 
A section of the book is devoted to the ways in which each of these features of female embodiment represents a potential hazard to women's career progression. An ironic, humorous tone continues in relation to age; the severe obstacle that ageing poses for women at work is reiterated throughout these later self-help texts:

'At a certain age, makeup may no longer be optional. You'll know the moment, because when you get there, coworkers may ask, "Oh, you're not feeling so well today, are you?"' Hardball for Women (2005)

Advising women not to wear their 'reading glasses around your neck' in case it makes one look old, the author of Nice Girls Don't Get the Corner Office (2004) goes on: 'At the risk of sounding ageist, I need to say once again that, unlike men, it's the rare woman who finds her credibility increasing with age'.

Overall, we see how humour is deployed in order to create a light-hearted and fun feeling. Irony is used throughout, where an author presents one message while clearly intending that the reader would read a different meaning into it (Trethewey, 1999b). So for example the statement 'they can cry, you can't', is clearly intended in a jokey manner, deploying irony to show that the author is disengaged from the literal meaning of the sentence, and does intend for it to be taken seriously.

\section{Reinforcing gender positions}

At first glance it might appear that recent self help books propose a swapping around of traditional gender roles. Women are encouraged to 'play like a man' and adopt masculine characteristics, for example: 
'It's important to look strong... Draw yourself up to your full height and square your shoulders.' Hardball for Women (2005).

In this way, women can apparently 'play' with aspects of the body in order to approximate a masculine ideal. On closer examination however it appears that what seems to initially represent a challenge to masculine norms is in fact a strict reinforcement of heteronormative positions of gender and sexuality.

'In certain situations, a little cleavage can actually help to first peak a guy's attention to a career girl's benefit, then later help to distract a guy's attention to a career girl's benefit' Hardball for Women (2005).

This suggests that in the absence of a penis, perhaps a set of breasts can substitute for a symbol of power. What was a heteronormative performance of masculinity is simply reversed. In How to Succeed in Business Without a Penis (1997), Salmonsohn discusses the issue of using one's perceived sexuality for gain, and where necessary, flirting in order to get ahead:

'Repression of one's sexuality can be a repression of power that otherwise focused correctly could be quite a persuasive force'.

In the following example, this reinforcement of gendered positions of heteronormative sexuality is taken to an extreme:

'What happens at the urinal can be off limits to you unless you're someone like Jackie. I was preparing to work with the board of directors of a national medical society. The chair brought me up to speed about Jackie, the only woman on the board. He 
described her as "tough as nails." It seems that during the break at a previous board meeting, four of the members, including Jackie, were walking down the hall discussing the politics of the organization. The three men made a turn into the men's room. Jackie followed right along behind them. They were stunned and asked her "What's up?"

"You weren't going to have this conversation without me, were you?"

The chair told me that the men are now very careful about discussing board issues in the restroom because they're afraid Jackie will come in.' Hardball for Women (2005).

While it might be argued that Jackie is playing with traditional gender norms and entering a space normally reserved for masculine bodies, in fact the inclusion of this story serves as a warning to readers and as such represents a reification of such norms. Jackie is indeed transgressing the norms of gender that might be expected of her, but her actions are presented as an extreme act. Despite her obvious inhabitancy of the category women, she demands entry into a space normally reserved for men. The inclusion of this story is intended to shock and in this way, the boundary between women and men is reinforced and awareness of the division is underlined. This distinction is emphasised again in the following excerpt, in which the author notes how traditionally, power and masculinity are seen as synonymous, with power and femininity being considered almost mutually exclusive. However, this need not be the case, because of the importance and strength of one's position as a woman:

'Being a woman is a large part of who we are. We can't feel good about ourselves and not feel good about our femininity... To be comfortable with her power, a woman 20 
must be both powerful and feminine. She can't be powerful in the same way as a man because she is judged on women's standards. Nevertheless, she can be clear on her goals and she can hold onto them tenaciously, without resorting to tantrums, foul language, or other male power-grabbing behavior.' Hardball for Women (2005).

This implies that a woman's femininity is foundational and all-influencing. However, the use of femininity will always be contingent on restraint as 'she will always be judged on women's standards', and subject to a monitoring gaze, as discussed in the section that follows.

\section{The male gaze}

A key part of managing one's body, in recent self-help books, involves adopting the position of the external viewer. To overcome the issue of being either overly bubbly, or not enthusiastic enough (both features of Mistake 76), for example, Dr Frankel advises women to consciously try and strike a balance between the two:

'One way to do this is to observe yourself on a videotape with the sound off. If you were standing outside the meeting, looking through a glass partition, how would you describe the woman you see?' Nice Girls Don't Get the Corner Office (2004)

The reader is advised to approximate the external gaze and retain this always at the forefront of her mind. Interestingly, the focus is always outward, on the person who is watching the woman manager reader. The 'signals' being sent to others are seen as the most important aspect of embodied life. This is clear throughout: 
'A woman's wardrobe (as opposed to a man's) is a vital part of our presentation. It tells our colleagues what we're all about. Do you want others to think you're a plodder or an iconoclast? Are you creative, gregarious, secure? Are you conservative, timid, self-conscious? Your wardrobe has the power to convey all these messages' Play Like a Man (2004)

The gaze is again apparent in relation to one's body and sexuality. In the same text, the author tells a story about a former colleague, a woman whose 'outfits are attractive but a little too tight'. She describes the outfits:

'They show off her excellent figure, but they are inappropriate- so much so that her male associates feel uncomfortable around her. One colleague told me he was reluctant to have business dinners with her alone because he worried about what his wife would think.' Play Like a Man (2004)

In many cases, authors refer to the fact that they are focusing on the 'external gaze', and make a joke about this or apologise for it. Again, this reflects the light-hearted tone in which many of the texts are written:

'(Mistake 78): Makeup is tricky. On the one hand, I don't want to perpetuate Madison Avenue's image of what a woman should look like. On the other, I know it's something people notice when its too heavy or too light... Wearing too little can diminish your credibility as much as wearing too much'. Nice Girls Don't Get the Corner Office (2004) 
The author initially refrains from suggesting that career women must constantly be focused on the gaze, but at the same time, what 'people notice' is a vital aspect of self-presentation.

This illustrates a common theme within these books: it is the gaze of the male colleague that ultimately matters in how women present themselves. Relating to the list of activities that are deemed unacceptable for women, above (e.g. 'They can be ugly. You can't'), for the author of Play Like a Man (2004), it is the fact that men view these traits negatively, that poses the real danger. For example, discussing the issue of fidgeting, she notes that:

'Guys consider a woman's annoying little habits exactly that - annoying little habits. To them, she's broadcasting to the world that she is uncomfortable, insecure, flustered. When a man is tapping, however, it usually means he's impatient. Thus it tends to be a power play.'

In relation to weight, the author of Play Like a Man evokes the male gaze when she advises that:

'Despite some enormous advances in their consciousness, men still seem to believe that every woman wants to be thin. And if she isn't, they assume she must have poor self-control, a problem which they fear could slip over into her work'.

In Hardball for Women (2005), the opinion of a man is again given centre stage:

'I was once conducting a workshop on working in a man's world for the female managers of a company. In the next room, William was conducting a parallel 
workshop with the male managers on how to work with women... [I] asked him what the men found most difficult about working with women. William looked me in the eye and said, "Menstruation."

.... I've asked several other men what they thought about this issue. I was surprised to learn that the attitude William expressed was very common. In fact, one individual referred to executive row as "menstrual alley" because so many of his company's executives were women.'

The external gaze is central and in many cases, this gaze is masculine.

'Many men perceive menstruation as an alien thing that invades our bodies and controls us. For instance, one fellow asked me, "Well, what if the president had a period?", as if the leader of the Free World had never seen a bad day. Having never experienced it, they imbue the menstrual cycle with meaning and power it doesn't have. In fact, menstruation is a deeply mysterious process for men. And to add to its mystery, it's somehow tied to the phases of the moon.' Hardball for Women (2005) The esteem accorded to the opinion of men is clear. In the case of those mentioned above, we are not told the status or position within the organization of 'one fellow' and 'William', merely that they are men and, implied in this, that their opinion is of intrinsic value.

The importance of privileging male opinion is evoked again in relation to the common issue of women's soft voices: 
'Men will tell you that women are too timid when they talk at the office, or too evasive, or too circuitous, or too unsure of themselves.' Play Like a Man (2004)

Men's reaction to women crying ('they are terrified') is given centre stage in Hardball for Women (2005). The fact that 'guys' assume that women have no sense of humour is also raised as an issue, alongside some tips for women that wish to hide this deficiency:

'Even if you can't tell a funny story, let your associates know you appreciate theirs. Sometimes that may mean laughing at things you don't find very humourous.' Play like a Man (2004).

Again, the fact that men don't see women as funny, is the key issue. The books analyzed for this paper are replete with examples of situations in which career women are told to focus on 'what men think' and design their behaviour accordingly. All this is presented with the light-hearted and fun tone that characterizes recent self-help books aimed at career women.

\section{Ironic humour as discipline}

In some cases, the humorous tone turns harsh and instructive:

'If a woman seems too masculine she will be labeled "bitch", "barracuda", or worse.' Hardball for Women: Winning at the Game of Business (2005).

'It is often the details which let you down. The state of your hair, skin, and nails can tell someone that you don't have time in the morning to get ready properly, that you 
are stressed, tired or downright careless.' In Good Company: The Essential Business Start-Up Guide for Women (2006)

Here, we can see that the tone is abrupt and almost scolding. Women must avoid letting their inherent carelessness be known. While men will be forgiven for such slips, a woman will not enjoy such 'immunity'. The pitfall of carelessness is reiterated in Play Like a Man (2004):

'Just as they get away with social mistakes, men are likely to enjoy immunity from errors in their physical appearance- stained ties, missing buttons, mismatched socks. But no woman, no matter how important, seems to escape censure for even the tiniest sartorial flaw. It's as though such a lapse were a sign that she doesn't know, or doesn't care, or doesn't pay attention to details.'

Again, the spectre of the slothful, careless woman appears. The dangers of drinking alcohol when in a restaurant for lunch, as part of networking, are emphasized:

'[In some situations] for you to [drink alcohol] would make you appear like the local lush, even if you just have a single glass of wine when you go out to dinner with your colleagues. Even if the guys call for a pitcher of beer and get blasted, your joining in somehow immediately compromises you and makes you a potentially loose woman. As we've seen so many times before standards are different for women.' Hardball for Women (2005)

The texts exhibit a playful, informal approach to dispensing advice but in many cases, this represents a thin veneer over a sharp criticism of what are perceived to be 
women's inherent tendencies, and a harsh injunction to obey a perceived norm of embodiment. In the following anecdote, a transgressive woman is described:

'One very smart woman I know can never really get ahead. Overweight, she dresses like a hippie in shapeless clothes designed to hide her body. Her company has carefully moved her out of positions of power and excluded her from meetings with outside executives. The more distance between her and the big bosses, the more she hides in her clothing. Her fears, first reflected in her dress, have become a selffulfilling prophecy.' Play Like a Man, Win Like a Woman: What Men Know about Success that Women Need to Learn (2000).

Here, this woman serves as a symbol of all the dangers that lie in wait for those that do not subscribe to the embodied norm advocated by such self-help books. Again, this stark warning is relayed in a friendly and light-hearted manner. Humour is deployed in relation to transgressions of a bodily norm, in order to reinforce the dangers of such transgressions.

This instructive, disciplinary impulse is perhaps most obvious when it appears alongside contradictory discourses aimed at career women. For example, rather than adhering to a strict and clear norm of self-presentation, individuality in dress and comportment is presented as essential. The author of Play Like a Man, for example, repeatedly discusses Madeleine Albright's wearing of a large and distinctive brooch on her lapel. This pin is presented as a perfect example of individuality within conformity: 
'Its purpose is to suggest her individual style and her femininity without deviating too much from the appropriate uniform of the highest-ranking member of the president's cabinet. The bottom line: Dress for the team, but do it with confidence, creativity and within the range of your own personal comfort.'

Thrift (2005) points to the apparent rise of a 'self-discovering subject' related to knowledge economy cultural products such as self-help books. Here we see that women are at once encouraged to embark on such a journey of self-discovery, to find their 'inner selves' while simultaneously being cautioned not to stray too far from the prescribed embodied norms. The paradox of this individuality-within-conformity is exemplified in Hardball for Women (2005), in which women are reminded to 'stay true to their inner selves' at all times. However, women are told that despite this, 'you need to dress in a way that doesn't single you out as being different'. The confusing advice continues, as women are told in no uncertain terms that any effort to consciously manipulate their image will come across as ridiculous:

'The woman who tries to change her inner self to fit into her work environment will always be the proverbial square peg. There she is, pretending to be a tigress, but in reality she's a pussycat wanting to be loved. She's a walking hypocrite, and she knows it. The lie makes her miserable, others pick up on that and soon no one neither her office mates nor the woman - knows who she really is.' Play Like a Man (2004).

Here, despite repeated advice that women must change themselves in order to fit in, the woman that follows this advice is criticised and called a 'walking hypocrite'. 
If you become overly self-conscious of what you wear or look like, then you will lose focus', How to Succeed in Business without a Penis (1997)

There is confusion and ambiguity at the heart of much of the advice provided to women by such texts. What we see here is a clear instruction to avoid making this struggle obvious in any way.

In summary, in our sample of recent self-help books aimed at women managers there are similarities with self-help books influenced by second-wave feminism published in the 1980s and early 1990s. The female body is presented as a source of otherness, and advice is given on how to overcome this as a means of achieving gender equality in the workplace. In more recent texts influenced by discourses of neoliberalism in the context of third-wave feminism however, the tone of this advice has changed. It has become more humorous but also more disciplinary. This finding gives support to the notion that the hyper-individualism associated with neoliberalism may give women access to subject positions previously closed to them but it also constrains them in what they may become and how they can practice resistance (Rich, 2005).

\section{Discussion and conclusions}

Questions of how the body is performed are vital in understanding the knowledge economy and its emergent working cultures. The body constitutes a medium through which cultural norms and values are acquired, and through which proficiency as a member of such cultures is demonstrated (Thrift 2005; Shilling, 2007). Self-help books form an important part of this process. We see here how such texts encourage the career woman to monitor and package her body. Individuality is encouraged, but 
only within strictly controlled parameters of 'fitting in' with wider neoliberal norms. Moreover, the presence of an external, male gaze that anchors this monitoring process is central.

Our analysis points to a shift in tone in self-help books published in the last fifteen years: from sincere helpfulness to ironic humour. Self-help texts advocate acceptance of the status quo in which the masculine bodily norm dominates in organizations and in which women are required to 'perform in terms of prescriptions gendered as masculine' (Acker, 2004: 31), even though it is acknowledged that such gendered dispositions are impossible for women to achieve. Even in the use of light-hearted, game analogies and book titles, we see how the otherness of the woman manager persists. While the extensive use of sporting metaphors such as 'winning the game' and 'playing hard ball' seem ironic and playful, these choices of metaphors reproduce the view that management is an inherently masculine activity (McDowell, 1997; Hall, 2013). Differences between men and women are highlighted and emphasized throughout the self-help books studied here, as exemplified in the title 'How to Succeed in Business without a Penis', and again in this text's contents, in which the author notes that one of her goals in writing the book is to 'show how women should not fight their female side, but rather learn to use it in their fight to attain career enhancement'.

Importantly, humour provides the means through which authors navigate this fundamental tension. A humorous approach is employed when drawing attention to the woman manager's abnormal body relative to the masculine norm, giving an impression of informality and implying that the advice offered in such texts are 30 
merely light-hearted tips that can be taken or rejected as women see fit. A sense of freedom to choose is therefore embedded within this humorous approach; an ideology is promoted in which women are liberated to create themselves at will. On closer examination however, it appears that the playful tone conceals a critique of women who transgress the norms that they are expected to follow. The ironic veneer enables a forceful denunciation of such renegades, who are presented as a symbolic warning to the reader. This is exemplified in the case of the 'hippie' ex-colleague portrayed in Play Like a Man (2004), and in Jackie's outrageous trip to the urinals.

Irony is key in achieving this denunciation. As noted above, the use of irony as a communication strategy can have the paradoxical impact of showing both adherence to current social norms while simultaneously producing an impression of the author's separation from them (Trethewey, 1999b). Juxtaposing 'seriousness and play' (ibid: 143), the typical author in our sample above presents an impression of cynical distance, laughingly suggesting that she is critical of gendered norms in contemporary organizations, and yet the overall message is one of conformity. On this point, Butler (1990) draws on Foucault's idea that ironic and humourous critiques can provide a comforting illusion that power is open to question and to alteration, when in practice they frequently do no such thing. This 'false resistance' can thereby reinforce existing relations of domination, by giving the impression that a challenge has been mounted (Gherardi, 1995; Foucault, 1990). Interestingly in the context of self-help literature a commercially successful form of publishing, Butler notes that this illusion is often strongest where the form of 'subversion' in question 'carries market value' (1990, p. xxi). A cultural circuit of the kind described by Thrift ensues, in which problems are 
apparently solved by 'helpful' advisors who paradoxically maintain the problem itself, through the proliferation and sale of such cultural products.

Our analysis adds to debates on how humour can be used as a disciplinary mechanism. While scholars have noted an increasing normative emphasis on embodied performances by 'self-discovering subjects' within the knowledge economy, we provide insights into how these mechanisms operate via the growing genre of selfhelp, and how they are intensified through the use of ironic humour. Apparent fun and freedom are part of an intensified reinforcement of gender norms, along with a stricter injunction to discipline oneself. While a discourse of individuality and fun is promoted, this is accompanied by instructions to be constantly alert to the heterosexual male gaze, and to modify and style one's body accordingly. Relatedly, the shift in tone noted above may be intended to appeal to younger feminists who are more likely to advocate an individualistic style of feminism in the neoliberal economy (Stevenson et al., 2011).

These observations lead to questions of whether women can ever really manage our/ their feminine, sexed bodies in ways that fit in work organizations. What do the above observations mean for career women working in the knowledge economy? It is useful to return to the point that paradox and contradiction mark the self-help books studied here. The observations presented above reflect what other authors have termed the delicate 'balancing act' that is required in order for working women to avoid appearing either too masculine or excessively feminine (Hochschild, 1994; McDowell, 1997; Trethewey, 1999a; Hall, 2013). The career woman is, as Trethewey notes, caught in a series of "complex, ambiguous, and precarious "in-betweens", 32 
(1999a: 425). Gender dynamics are acknowledged as a structure that constrains women in work organizations but at the same time gender inequity is constructed as something that the individual can overcome. Here, it is useful to draw on Irigaray, who suggests that perhaps there exists no ontological place for the feminine in such discourses (1990). For Irigaray, rather than being a separate, sovereign subject, the category of woman is always subsumed to a position of strangeness and otherness. It can ever only be understood relative to man, as his reflection, 'the other of the same'. Self-help books, through their insistence that their female readers approximate a male gaze in order to monitor themselves, and through their proffering of paradoxical and contradictory advice, merely serve to reinforce this absence of the female position.

Finally, these observations point to the question of the effects of self-help texts on women's embodied experience of knowledge economy cultures. Are they simply tools in the ongoing dominance of a hegemonic, masculine organizational norm or do they leave scope for resistance? Any attempt to answer this must engage with the ways in which such texts are taken up. There is a need to explore how career women use these books in their everyday lives as a means of recognising and voicing their own interests and aspirations. It may be that in situations where career women find themselves 'lone travellers' (Marshall, 1984) in a masculine world, such books enable them to feel connected to others in the same situation and develop a coherent selfidentity (Simonds, 1992: 6).

What we can say is that self-help books play an important role in legitimating and reproducing cultures of work in the context of neoliberalism and the knowledge economy. In this paper we have highlighted a shift in tone as self-help books for 33 
career women adopt a more light-hearted, humourous style of writing. In contrast to hopes of greater equality for women within the knowledge economy, it appears that disciplinary control of embodied performances has in fact intensified, fuelled by neoliberalistic values of self-sufficiency, self-discipline, entrepreneurialism and personal responsibility, and that this effect may be heightened by the use of humour in recent self-help texts. As others have noted, the presentation of informal advice can thus enable traditional gender norms to remain in place. Where readers experience confusion and ambiguity, these rules are followed from an estranged distance (Hochschild, 1983, 1994), but it appears that they must be followed nonetheless. 


\section{References}

Authors (2011)

Acker, J. (1990) 'Hierarchies, Jobs, Bodies: A Theory of Gendered Organizations', Gender and Society, 4(2): 139-58.

Acker, J. (2004) ‘Gender, capitalism and globalization', Critical Sociology, 30(1): 17 41.

Andriopoulos, C. and Gotsi, M. (2001) “Living” the Corporate Identity: Case Studies from the Creative Industry'. Corporate Reputation Review, 4(2): 144-154.

Bate, B. and Self, L.S. (1983) 'The Rhetoric of Career Success Books for Women', Journal of Commmunication, 33(2): 149-165.

Biggart, N. W. (1983) 'Rationality, Meaning and Self-Management: Success Manuals 1950-1980', Social Problems, 30(3): 298-311.

Bolton, S. and Houlihan, M. (2002) 'Tensions and Variations in Call Centre

Management Strategies', Human Resource Management Journal, 12(41): 67-85.

Burrell, G. (1992) 'Sex and Organizations', in A.J. Mills and P. Tancred (Eds.), Gendering Organizational Analysis. London: Sage.

Butler, J. (1990) Gender Trouble. London, Routledge.

Clark, T. and Salaman, G. (1998) 'Telling tales: Management gurus' narratives and the construction of managerial identity', Journal of Management Studies, 35, 137-61. 
Cockburn, C. (1991) In the Way of Women: Men's Resistance to Sex Equality in Organizations. London: Macmillan.

Collinson, D. (1992) 'Managing the Shopfloor': Subjectivity, Masculinity and Workplace Culture. Berlin: de Gruyter.

Cooper, C. (2005) 'Just Joking Around? Employee Humor Expression as an Ingratiatory Behavior'. Academy of Management Review, 30(4): 765-776.

Crainer, S. (1996). The rise of guru skepticism. Management Today. March: 49-53.

Dean, D. (2005) 'Recruiting a self: Women performers and aesthetic labour', Work, Employment and Society, 19(4): 761-774.

Eaton, S. (1999) 'Surprising opportunities: gender and the structure of work in biotechnology firms', Annals of New York Academy of Sciences, 869, 175-88.

Ehrenreich, B. (2006) Bait and Switch: The Futile Pursuit of the Corporate Dream. London: Granta.

Evans, G. (2000) Play Like a Man, Win Like a Woman: What Men Know about Success that Women Need to Learn. Broadway Books.

Fleming, P. (2007). 'Sexuality, power and resistance in the workplace', Organization Studies, 28: 239-256.

Flett, C.V. (2007) What Men Don't Tell Women About Business: Opening Up the Heavily Guarded Alpha Male Playbook. Wiley \& Sons. 
Frankel, L.P. (2004) Nice Girls Don’t Get the Corner Office: 101 Unconscious Mistakes That Women Make. Business Plus.

Foucault, M. (1990) The History of Sexuality: Volume 1, An Introduction. London: Penguin.

Friedman, C. and Yorio, K. (2004) The Girl's Guide to Being a Boss: Valuable Lessons and Smart Suggestions for Making the Most of Managing. A\&C Black Publishers.

Gherardi, S. (1995) Gender, symbolism and organizational culture. London: Sage.

Greatbatch, D. and Clark, T. (2003) 'Displaying Group Cohesiveness: Humour and Laughter in the Public Lectures of Management Gurus'. Human Relations, 56, 12: $1515-1544$.

Hall, S. (2013) 'Business education and the (re)production of gendered cultures of work in the City of London', Social Politics, 20(2): 222-241.

Hancock, P. and Tyler, M. (2000) 'The look of love: gender, work and the organization of aesthetics', in Hassard, J., Holliday, R. and Willmott, H. (Eds.). Body and Organization, Sage, London.

Harding, N. (2013) On Being At Work: The Social Construction of the Employee. London: Routledge.

Heim, P. with Golant, S.K. (2005) Hardball for Women: Winning at the Game of Business. Plume Books. 
Hochschild, A. (1983) The Managed Heart: Commercialization of Human Feeling.

Berkeley: University of California Press.

Hochschild, A. (1994) 'The Commercial Spirit of Intimate Life and the Abduction of Feminism: Signs from Women's Advice Books', Theory, Culture and Society, 11: 124.

Huczynski, A.A. (1993). Management Gurus. London: Routledge.

Irigaray, L. (1990/2007) Je, Tu, Nous: Towards a Culture of Difference. Translated by A. Martin. New York: Routledge.

Jackson, B. (2001) Management Gurus and Management Fashions. London: Routledge.

Joseph, M. (2013) 'Gender, entrepreneurial subjectivity and pathologies of personal finance', Social Politics, 20(2): 242-273.

Jordan, R. and Weir, K. (2006) In Good Company: The Essential Business Start-Up Guide for Women. A\&C Black Publishing.

Kahn, W. H. (1989) 'Toward a Sense of Organizational Humor: Implications for Organizational Diagnosis and Change'. The Journal of Applied Behavioral Science, 25 (1): 45-63.

Kenny, K. and Euchler, G. (2012) Some good, clean fun: Humour, control and subversion in an advertising agency. Gender Work and Organization, 19(3): 306-323. 
Koester, J. (1982). The Machiavellian princess: Rhetorical dramas for women managers. Communication Quarterly, 30, 165-172.

Kuipers, G. (2006) 'The social construction of digital danger: debating, defusing and inflating the moral dangers of online humor and pornography in the Netherlands and the United States'. New Media and Society, 8, 379-400.

Larner, W., Fannin, M., MacLeavy, J. and Wang, W.W. (2013) 'New times, new spaces: Gendered transformations of governance, economy, and citizenship', Social Politics, 20(2): 157-164.

Marshall (1984) Women Managers: Travellers in a Male World. Chichester: Wiley.

McDowell, L. (1997) Capital Culture: Gender at Work in the City. Oxford: Blackwell.

McGee, M. (2005) Self-Help, Inc.: Makeover Culture in American Life. Oxford:

Oxford University Press.

Montuori, A. (2003) 'The complexity of improvisation and the improvisation of complexity: Social science, art and creativity'. Human Relations, 56, 2, 237-255.

Mulvey, L. (1975) 'Visual Pleasure and Narrative Cinema', in L. Mulvey Visual and Other Pleasures, pp. 14-26. Basingstoke: Macmillan.

Nadesan, M.H. and Tretheway, A. (2000) 'Performing the enterprising subject:

Gendered strategies for success(?)', Text and Performance Quarterly, 20(3): 223-250.

Nonaka, I. and Takeuchi, H. (1995) The Knowledge-Creating Company. Oxford: Oxford University Press. 
Parker, (2007) “"The Little Book of Management Bollocks” and the culture of organization'. In R. Westwood and C. Rhodes (eds) Humour, Work and Organization. Abingdon: Routledge, 77-92.

Rich, E. (2005) 'Young women, feminist identities and neoliberalism', Women's Studies International Forum, 28: 495-508.

Rose, N. (1989) Governing the Soul: The Shaping of the Private Self. London:

Routledge.

Salmonsohn, K. (1997) How to Succeed in Business Without a Penis: Secrets and Strategies for the Working Woman. Pan Books.

Schneider, L. and Dornbusch, S. (1958) Popular Religion: Inspirational books in America. Chicago: University of Chicago Press.

Sennett, R. (1998) The Corrosion of Character. London: W.W. Norton.

Shilling, C (2007) 'Sociology and the body: classical traditions and new agendas' in C. Shilling (Ed.) Embodying Sociology: Retrospect, Progress and Prospects, pp 1-18, Oxford: Blackwell/The Sociological Review.

Simonds, W. (1992) Women and Self-Help Culture: Reading Between the Lines. New Brunswick, N.J.: Rutgers University Press.

Sinclair, A. (2005) 'Body and Management Pedagogy’, Gender, Work and Organization, 12(1): 89-104. 
Stevenson, D., Everingham, C., Robinson, P. (2011) 'Choices and life chances:

Feminism and the politics of generational change', Social Politics, 18(1): 125-145.

Thrift, N. (2005) Knowing capitalism. London: Sage.

Thurow, L. (2000) 'Globalisation: the Product of a Knowledge-Based Economy', Annals of the American Academy of Political and Social Science, Thousand Oaks, July 2000 .

Trethewey, A. (1999a) 'Disciplined Bodies: Women's Embodied Identities at Work', Organization Studies, 20(3): 423-450.

Trethewey, A. (1999b) 'Isn't it ironic: Using irony to explore the contradictions of organizational life'. Western Journal of Communication, 63(2): 140-167.

Truss, C. et al. (2012) 'Knowledge work: Gender-blind or gender-biased?', Work, Employment and Society, 26(5): $735-754$.

Wajcman, J. (2004) Technofeminism. Cambridge: Polity Press.

Walby, S. (2007) 'Introduction: Theorizing the Gendering of the Knowledge Economy: Comparative approaches', in Walby, S., Gottfried, H., Gottschall,K. and Osawa, M. (eds.) Gendering the Knowledge Economy: Comparative Perspectives. Basingstoke: Palgrave Macmillan, pp. 3-50.

Whitford, M. (1991) The Irigaray Reader. Oxford: Blackwell.

Witz, A., Warhurst, C. and Nickson, D. (2003) 'The labour of aesthetics and the aesthetics of organization', Organization, Vol. 10, No. 1, pp.33-54.

41 
Wodak, R. (2004) 'Critical Discourse Analysis', in C. Seale, G. Gobo, J. F. Gubrium and D. Silverman (Eds.) Qualitative Research Practice, pp. 197-213. London, Sage.

\footnotetext{
${ }^{\mathrm{i}}$ Although this text was first published in 1992, the book's continuing success, and the publication of a new edition in 2005, makes it worthy of inclusion in our sample.
} 